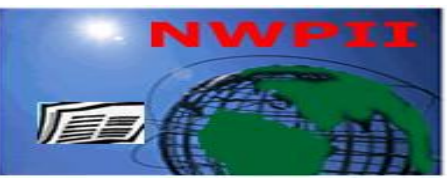

American Journal of Biomedical Sciences

ISSN: 1937-9080

nwpii.com/ajbms

\title{
Expression Pattern of MALAT-1 Gene and Oxidative DNA Damage in Nigeria Men with Prostate Carcinoma
}

\section{Idomeh Festus Aigbokheo1, Osadolor Humphery Benedo²,Osaigbovo Emmanuel O. ${ }^{3}$, Obahiagbon Ikponmwonsa ${ }^{4}$,Idomeh Joyce Eberechukwu}

\author{
${ }^{1}$ Department of Medical Laboratory Sciences, School of Basic Medical Sciences, University of Benin, Benin City, \\ Edo State, Nigeria.Email: festusidomeh@gmail.com \\ ${ }^{2}$ Department of Medical Laboratory Sciences, School of Basic Medical Sciences, University of Benin, Benin City, \\ Edo State, Nigeria.Email: Humphrey.osadolor@uniben.edu \\ ${ }^{3}$ Department of Surgery, University of Benin Teaching Hospital, Benin City, Edo State, Nigeria.Email: \\ emmyosa2000@yahoo.com \\ ${ }^{4}$ Department of Pathology, University of Benin Teaching Hospital, Benin City, Edo State, Nigeria.Email: \\ ikflex@yahoo.com \\ ${ }_{5}^{5}$ Department of Marine Environment and Pollution control, Nigeria Maritime University, Okerenkoko, Delta State. \\ Nigeria.Email: joyceidomeh@gamil.com \\ "Corresponding Author \\ Idomeh Festus Aigbokheo \\ Department of Medical Laboratory Sciences, School of Basic Medical Sciences, University of Benin \\ Benin City, Edo State \\ Nigeria \\ Email: festusidomeh@gmail.com \\ Phone Number: +2348074416855
}

Received:13 April 2019; | Revised:21 May 2019; | Accepted:09 December 2019

\begin{abstract}
Prostate cancer is fast becoming a global burden with negative consequence on the socio-economic status of affected persons around the world. This case control study examined the expression pattern of Metastasis-associated Lung Adenocarcinoma Transcript 1 (MALAT1) gene and levels of 8-Oxoguanine DNA Glycosylase $\left(\mathrm{OGG}_{1}\right)$, 8-Hydroxy-2 ${ }^{1}$-deoxyguanosine $(8-\mathrm{OHdG})$, Cadmium $(\mathrm{Cd})$ and $\mathrm{Lead}(\mathrm{Pb})$ in prostate cancer patients of Nigerian origin. A total of fifty-two (52) patients were recruited for this study from the urology clinics of University of Benin Teaching Hospital and Faith Mediplex Hospital, Benin City. They were grouped into A: Prostate cancer patients (CAP), B: Benign prostatic hyperplasia (BPH) and C: apparently healthy participants. Serum blood samples obtained from participants were used to assay for OGG1 and 8-OHdG as markers of DNA damage using ELISA techniques and toxic metals $(\mathrm{Cd}$ and $\mathrm{Pb})$ using Inductively Coupled Plasma Mass Spectrophotometer (ICPMS) based on standard methods. Results showed a significant up regulation of MALAT1 gene in CAP and some BPH patients compared to controls $(\mathrm{P}<0.001)$. Significantly lower mean levels $(\mathrm{P}<0.001)$ of OGG1 $(0.84 \pm 0.11)$ were observed for CAP patients when compared with other groups. However, a significantly higher mean level of 8-OHdG (97.24 \pm
\end{abstract}


3.53) $(\mathrm{P}<0.001), \mathrm{Cd}(0.68 \pm 0.02)(\mathrm{P}=0.003)$ and $\mathrm{Pb}(14.46 \pm 0.39)(\mathrm{P}=0002)$ was observed for CAP patients when compared with other groups. Our results which showed DNA damage as reflected in lower levels of plasma 8-Oxoguanine DNA Glycosylase and high levels of 8-Hydroxy-2 ${ }^{1}$-deoxyguanosine, is an evidence of genotoxic insult causing mutation in MALAT-1 gene. Consequently, MALAT-1 gene is up regulated in CAP patients indicating its clinical usefulness as a predictive, diagnosis and prognostic biomarker.

Keywords:Deoxyribonucleic acid damage, Metastasis-associated lung adenocarcinoma transcript 1, Inductively coupled plasma mass spectrophotometer

\section{Introduction}

Cancer is fast becoming a global burden with negative consequences on the socio-economic status of affected persons around the world. ${ }^{[1]}$ reported 14.1 million new cases and about 8.2 million cancer related deaths worldwide. Reports from GLOBOCAN 2012 reveal that prostate cancer incidence and mortality rates in Africa accounted for 23.2 and 17.0 per 100,000 respectively. ${ }^{[2]}$

The diagnosis of prostate cancer is mostly made in terminal stages due to the lack of specific and sensitive methods for early prostate cancer screening ${ }^{[3]}$. Though pathological biopsy is considered the gold standard for cancer diagnosis yet the invasiveness and risk of adverse effects limit its clinical use. There is a therefore a significant need to develop a noninvasive biomarkers ${ }^{[4]}$.

Reactive Oxygen Species (ROS) are chemically reactive molecules that play essential roles in humans. They are needed at low concentration for a number of physiological activities such as cell death, immune defense against pathogens, induction of mitogenic response, intracellular cell signalling and homeostasis ${ }^{[5]}$. Under oxidative stress conditions, free radicals generated in excessive amounts can result in severe damage to the DNA, proteins and lipids which a resultant compromise in cell health and development of diseases ${ }^{[6,7,8]}$.

8 -Hydroxy-2 $2^{1}$-deoxyguanosine $(8-\mathrm{OHdG})$ is one of the major oxidative modifications in the DNA generated by the hydroxylation of the deoxyguanosine residues. In an effective antioxidant defense system, it is usually excised from the DNA by enzymatic repair system resulting in its free circulation in the blood ${ }^{[9]}$.

8-Oxoguanine DNA Glycosylase $\left(\mathrm{OGG}_{1}\right)$ repairs oxidative DNA damage, $8-\mathrm{OHdG}$ being a major mutagenic lesion ${ }^{[10]}$. $\mathrm{OGG}_{1}$-initiated DNA base excision repair pathway $\left(\mathrm{OGG}_{1}-\mathrm{BER}\right)$ is a multistep process involving lesion recognition, changes in DNA structure, insertion of the 8oxoguanine containing DNA double helix into the active site, base excision and strand cleavage ${ }^{[11]}$. Decreased OGG1 activities due to cadmium toxicity have been reported in mouse and human models ${ }^{[12-}$ 14].

Long noncoding RNA (lncRNA) is an essential population of the noncoding RNAs (ncRNA) with a sequence of over 200 nucleotides [15]. They can be classified as tumour suppressor genes or oncogenes according to their specific function and expression pattern in tumour tissues ${ }^{[16]}$. Metastasis-associated lung adenocarcinoma transcript 1 (MALAT1) is a type lncRNAs and recent clinical studies have highlighted it as a promising biomarker to aid in cancer diagnosis and prognosis ${ }^{[17]}$. MALAT1, also known as nuclear enriched transcript 2 has been shown to be highly expressed and act as an oncogene in most malignant tumours, such as breast cancer, lung cancer and hepatocellular carcinoma (HCC) ${ }^{[18]}$. Previous studies also show that MALAT1 expression is positively correlated with poor prognosis and advanced stages of pancreatic and prostate cancer. However, the underlying mechanisms of MALAT1 involvement in CAP etiology and pathogenesis has not been fully elaborated ${ }^{[19-20]}$.

There is paucity of data in the use of long noncoding RNA in prostate cancer diagnosis and prognosis in Nigeria, hence the need for this study. In this study, the expression pattern of MALAT-1 gene and oxidative DNA damage were assessed in males with prostate cancer and benign prostatic hyperplasia to determine evidence of oxidative stress and gene mutation. 


\section{Materials and Method}

Subjects: This study was conducted at University of Benin Teaching Hospital and Faith mediplex Hospital urology outpatient clinics. Twenty six confirmed cases of males with prostate cancer, thirteen confirmed benign cases and thirteen apparently healthy control participants with an average age of between 40-79 years old were recruited for this study.

Ethics: Ethical approval (UBTH/ADM/ E 22/A/VOL. VII/14707) was obtained from the Ethics and Research Committee of University of Benin Teaching Hospital (UBTH), Benin, Nigeria.

Inclusion and Exclusion criteria: Patients with clinical evidence of prostate cancer and benign prostatic hyperplasia with no other histories of reproductive and endocrine system disorders, underlying disease or other forms of cancer who gave their consent were recruited in this study. Patients having urinary tract infection, prostatitis, history of treatment for prostate cancer and history of previous prostate surgery or treatments with drugs were excluded from the study.

Study design: Participants were grouped into A, $\mathrm{B}$ and $\mathrm{C}$; Prostate cancer patients (CAP) were classified as Group A ppositive rectal examination, PSA level of $>4 \mathrm{ng} / \mathrm{ml}$ and a positive prostate biopsy (Table 1) , Benign prostatic Hyperplasia (BPH) as Group B (positive rectal examination, PSA level $>4 \mathrm{ng} / \mathrm{ml}$ and a negative prostate biopsy), and apparently healthy participants as Group C (negative rectal examination, PSA level $<4 \mathrm{ng} / \mathrm{ml}$ ).

Table 1: Shows Gleason score and International Society of Urological Pathological (ISUP) Grade of Prostate Cancer Patients (Group A)

\begin{tabular}{cc}
\hline GLEASON SCORE & ISUP GRADE \\
\hline $3+4$ & II \\
$3+4$ & II \\
$3+4$ & II \\
$3+4$ & II \\
$3+4$ & II \\
$3+4$ & II \\
$3+4$ & II \\
$3+4$ & II \\
$3+4$ & II \\
$3+4$ & II \\
$4+4$ & IV \\
$4+4$ & IV \\
$4+4$ & IV \\
$4+4$ & IV \\
$4+4$ & IV \\
$4+4$ & IV \\
$4+4$ & IV \\
$4+4$ & IV \\
$4+4$ & IV \\
$4+4$ & IV \\
$4+5$ & V \\
$4+5$ & V \\
$4+5$ & V \\
$4+5$ & V \\
$4+5$ & V \\
$5+4$ & V \\
\hline
\end{tabular}

Collection of blood samples: Ten milliliters $(10 \mathrm{ml})$ of venous blood samples was obtained from each participants and dispensed into a one millilitre RNA shield tube for total RNA extraction, five (5ml) into EDTA tube for analysis of toxic metals and the other four $(4 \mathrm{ml})$ into an anticoagulant free specimen bottles plain tube for serum analysis of OGG1 and 8-OHdG (DNA markers of oxidative 
stress). The blood containing RNA shield tube was mixed by inversion and stored at $-20{ }^{\circ} \mathrm{C}$ until analysis. The other blood sample in a plain tube was allowed to clot and after 30 minute when the serum has retracted, it was spun at $4,000 \mathrm{rpm}$ for 10 minutes and the serum collected and stored in another anticoagulant free specimen bottle. The blood serum samples were stored at $2-8{ }^{\circ} \mathrm{C}$ until they were analysed.

Toxic metals determination: This was determined using Inductively Coupled Plasma Mass Spectrophotometer based on standard methods described by ${ }^{[21]}$.

Determination of 8-Oxoguanine DNA Gycoxylase activity (OGG1) level: This was determined by the sandwich enzyme immunoassay method (Cloud-Clone Corp., USA) ${ }^{[22]}$.

Determination of 8-hydroxy-2' deoxyguanosine (8-OHdG) levels: This was determined by enzyme linked immunosorbent assay method (Cloud-Clone Corp., USA) ${ }^{[23]}$.

Polymerase chain reaction methods: Total RNA was extracted using the ZR Whole - Blood RNA MiniPrep (Catalogue Nos: R1054 \& R1055) according to ZYMO RESEARCH specification. A $600 \mu 1$ volume RNA lysis buffer was added to 200 $\mu l$ volume of ribonucleic acid-shield (RNA Shield) stored whole blood sample in an RNase-free tube and mixed by inverting. The mixture was incubated for 5 minutes at $95^{\circ} \mathrm{C}$ in a heating block for complete homogenization and centrifuged at $\geqslant$ $10,000 \times \mathrm{g}$ RCF for 1 minute. The clear supernatant was transferred into a Spin-Away ${ }^{\mathrm{TM}}$ Filter (yellow) in a collection tube and centrifuged. A $800 \mu \mathrm{l}$ volume of ethanol $(95 \%)$ was added to the flowthrough and mixed properly. The resultant mixture was transferred into a Zymo-Spin IIIC column (green) in a collection tube and centrifuged at $\geqslant$ $10,000 \times \mathrm{g}$ RCF for 2 minutes and the flow-through discarded. The column was transferred into a new collection tube and $400 \mu \mathrm{l}$ volume of RNA Prep buffer was added to the column and centrifuge at $\geqslant$ $10,000 \times \mathrm{g}$ RCF for 1 minute and the flow-through discarded. A $700 \mu 1$ volume RNA wash buffer was added to the column and centrifuged at $\geqslant 10,000$ $\times \mathrm{g}$ RCF for 1 minute and the flow-through discarded. The column was transferred into a new collection tube and $400 \mu \mathrm{l}$ volume of RNA wash buffer was added to the column and centrifuge at $\geqslant$ $10,000 \times \mathrm{g}$ RCF for 2 minute to ensure complete removal of the wash buffer. The column was carefully transferred into an RNase free tube. Total RNA was eluted by adding $100 \mu \mathrm{l}$ volume of DNase/RNase free water directly to the column matrix and centrifuged at $10,000 \times \mathrm{g} \mathrm{RCF}$ for 30 seconds. A $100 \mu \mathrm{l}$ volume of the Total RNA extracted was transferred into an RNase free tube for storage of Total RNA at - $20^{\circ} \mathrm{C}$ while $10 \mu 1$ was used for quality control check on the Total RNA extracted.

One Taq One-Step reverse transcriptase polymerase chain reaction for prostate specific gene expressions: The extracted Total RNA was retrotranscribed and amplified using One Taq One Step RT-PCR kit with catalog number E5315S by NEW ENGLAND BioLabs incorporation according to the manufacturer's specification. Selected primers (Table 2.0) were used to target prostate specific genes using Applied BioSystems thermal cycler polymerase chain reaction machine. The PCR was performed in a $50 \mu \mathrm{l}$ volume reaction mixture containing $25 \mu \mathrm{l}$ volume of one Taq one-step reaction master mix $(2 x), 2 \mu$ l volume of One Taq one- step enzyme mix $(2 \mathrm{x}), 2 \mu \mathrm{l}$ volume of each gene-specific forward primer $(10 \mu \mathrm{M}), 2 \mu \mathrm{l}$ volume of each gene-specific reverse primer $(10 \mu \mathrm{M}), 9 \mu \mathrm{l}$ volume of nuclease-free water and $10 \mu \mathrm{l}$ volume of the RNA template was added. Negative controls samples for the RT-PCR consisted of a mixture to which all reagents added except RNA. The PCR was started immediately as follows: Reverse transcriptase at $48^{\circ} \mathrm{C}$ for 30 minutes, initial denaturation at $94^{\circ} \mathrm{C}$ for 1 minute, denaturation at $94^{\circ} \mathrm{C}$ for 15 seconds, annealing at $\mathrm{Tm}^{\circ} \mathrm{C}-5$ (The lowest melting temperature of each set of prostate primer minus five) for 30 seconds, extension at $68^{\circ}$ $\mathrm{C}$ for 1 minute, Go to the denaturation step for 39 cycles, final extension at $68^{\circ} \mathrm{C}$ for 5 minutes and final holding at $4^{\circ} \mathrm{C}$ forever. Ten micro liters of the amplified PCR products were analyzed on $1 \%$ agarose gel containing ethidium bromide in $1 \mathrm{X}$ Tris EDTA buffer. Electrophoresis was performed at 120 volts for 20 minutes with the NanoPAC-300 electrophoresis machine, Taiwan. The targeted genes were then visualized by PeQlab UV transilluminator and photographed. Molecular 
weights were calculated using molecular weight standard of the marker. The graphical analysis was done on a bar chart.

Statistical analysis: All results were analysed using one-way ANOVA with post hoc multiple comparisons test while student's t- test was used to compare independent variables. Gene expression results were analysed using Pearson Chi-Square test using SPSS version 20.0 statistical programs. P values $<0.05$ were considered significant.

Table 2: Assay condition for MALAT-1 gene evaluated and purchased from Inqaba Biotechnology Industries, Hartfield, South Africa

\begin{tabular}{|c|c|c|c|c|c|c|}
\hline Gene Symbol & Primer Sequence & $\begin{array}{l}\text { Molecular } \\
\text { Weight }\end{array}$ & $\mathrm{GC} \%$ & $\begin{array}{l}\text { Temperature } \\
(\min / \max )\end{array}$ & Length & $\begin{array}{l}\text { Ascession } \\
\text { Number }\end{array}$ \\
\hline $\begin{array}{l}\text { MALAT-1 } \\
\text { Forward }\end{array}$ & $\begin{array}{l}\text { GGGTGTTTACGTAGACCAGA } \\
\text { ACC }\end{array}$ & 7088.67 & 52.17 & 57.06 & 23 & GSE33455 \\
\hline $\begin{array}{l}\text { MALAT-1 } \\
\text { Reverse }\end{array}$ & $\begin{array}{l}\text { CTTCCAAAAGCCTTCTGCCTT } \\
\text { AG }\end{array}$ & 6934.56 & 47.83 & 55.25 & 23 & \\
\hline
\end{tabular}

\section{Results}

The reverse transcriptase polymerase chain reaction results for MALAT-1 gene revealed that the gene was detected at $95 \mathrm{bp}$ and $100 \mathrm{bp}$ on a $1 \%$ agarose gel electrophoresis stained with ethidium bromide in all the participants (CAP, BPH and Controls) respectively (Figures 1, 2, 3, 4 and 5).

Table 3 illustrate the mean levels of genotoxicity biomarkers (8-OHdG and OGG1) and toxic metals $(\mathrm{Cd}$ and $\mathrm{Pb})$ in Prostate cancer patients (Group A), Benign Prostatic Hyperplasia Patients (Group B) and the apparently healthy participants (Group C). 8-OHdG, cd and pb were observed to be higher $(\mathrm{p}<0.05)$ in group A compared to other groups. Prostate cancer patients however, reported a much lower level of OGG1 compared to other groups.

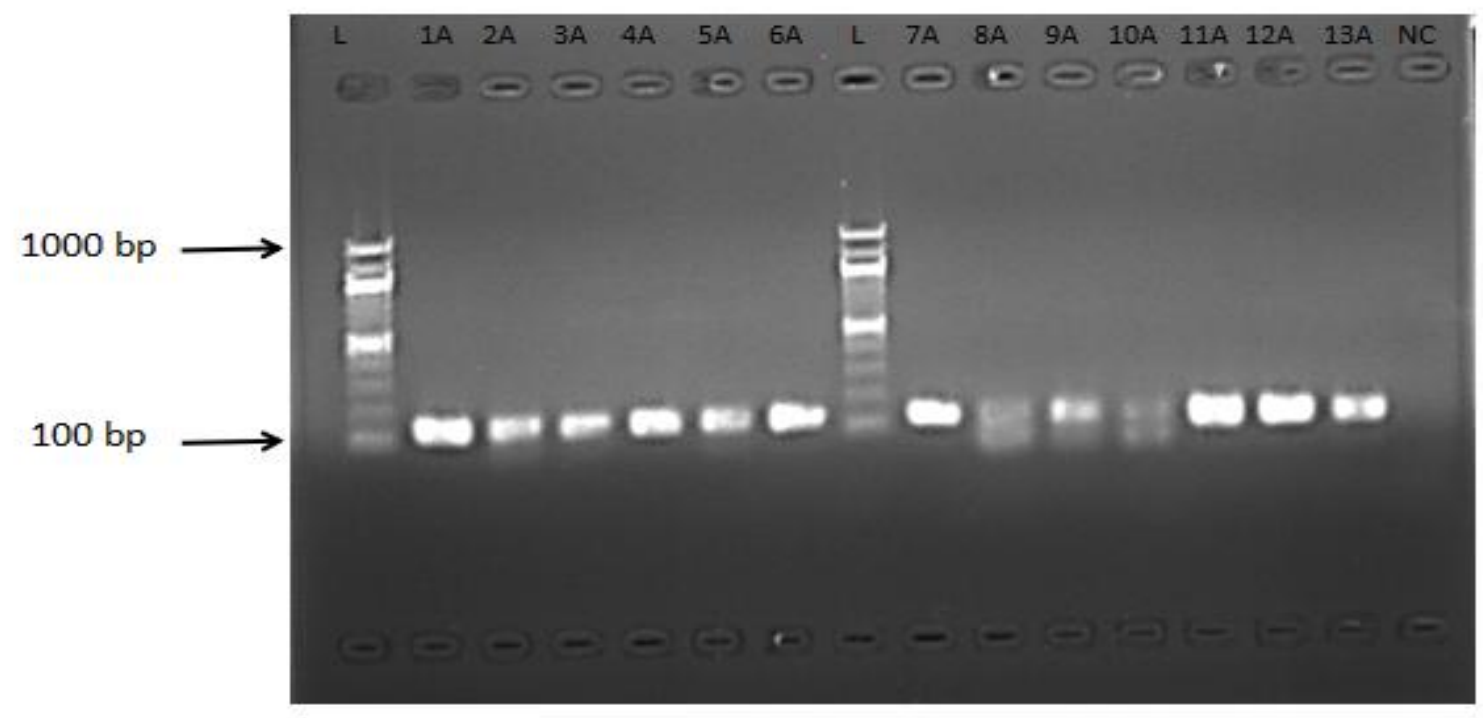

Figure 1: Reverse Transcriptase Polymerase Chain Reaction (RT-PCR) results for Metastatic Associated Long Adenocarcinoma Transcript 1 (MALAT 1) gene analysed on a $1.0 \%$ agarose gel electrophoresis stained with ethidium bromide. $\mathrm{L}$ is 100-1000 bp DNA ladder. A represents Prostate cancer participants. Samples 1A, 2A, 3A, 4A, 5A, 6A, 11A, 12A, and 13A are positive for MALAT-1 gene with bands at $100 \mathrm{bp}$. Samples 8A, 9A and $10 \mathrm{~A}$ are positive for MALAT-1 gene with bands at $95 \mathrm{bp}$ and $100 \mathrm{bp}$. Sample NC is a no template control. 


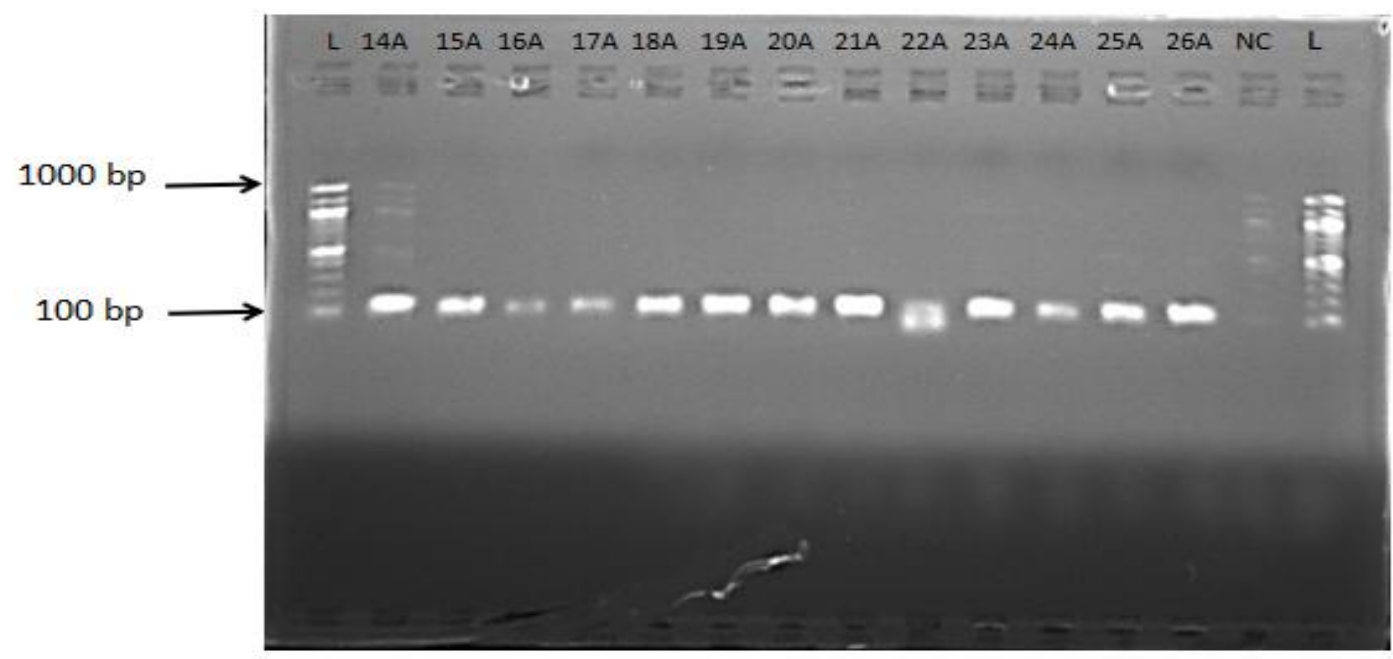

Figure 2: RT-PCR results for MALAT-1 gene analysed on a $1.0 \%$ agarose gel electrophoresis stained with ethidium bromide. $L$ is 100-1000 bp DNA ladder. A represents Prostate cancer participants. Samples 14A, 15A, 16A, 17A, 18A, 19A, 20A, 21A, 23A, 24A, 25A and 26A are positive for MALAT-1 gene with bands at $100 \mathrm{bp}$. Sample 22A is positive for MALAT-1 gene with bands at $95 \mathrm{bp}$ and $100 \mathrm{bp}$. Sample NC is a no template control.

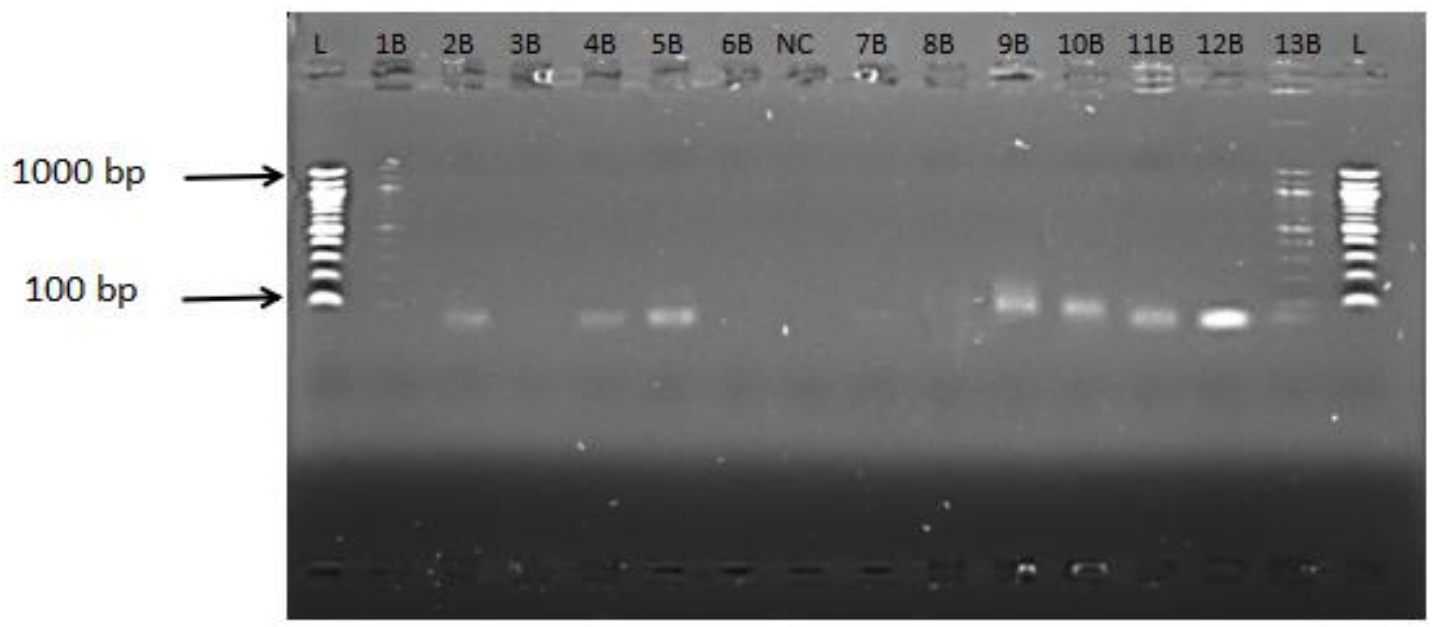

Figure 3: RT-PCR results for Benign Prostatic Hyperplasia Participants. Metastatic Associated Long Adenocarcinoma Transcript 1 (MALAT 1) gene was analysed on a 1.0\% agarose gel electrophoresis stained with ethidium bromide. $L$ is 100-1000 bp DNA ladder. $B$ represents Benign Prostatic Hyperplasia Participants. Samples 2B, 4B, 5B, 9B, 10B, 11B and 12B are positive for MALAT-1 gene with bands at 95 bp. Samples 1B,3B, 6B, $7 \mathrm{~B}, 8 \mathrm{~B}$ and $13 \mathrm{~B}$ are positive for MALAT-1 gene with bands at $95 \mathrm{bp}$. Sample NC is a no template control.

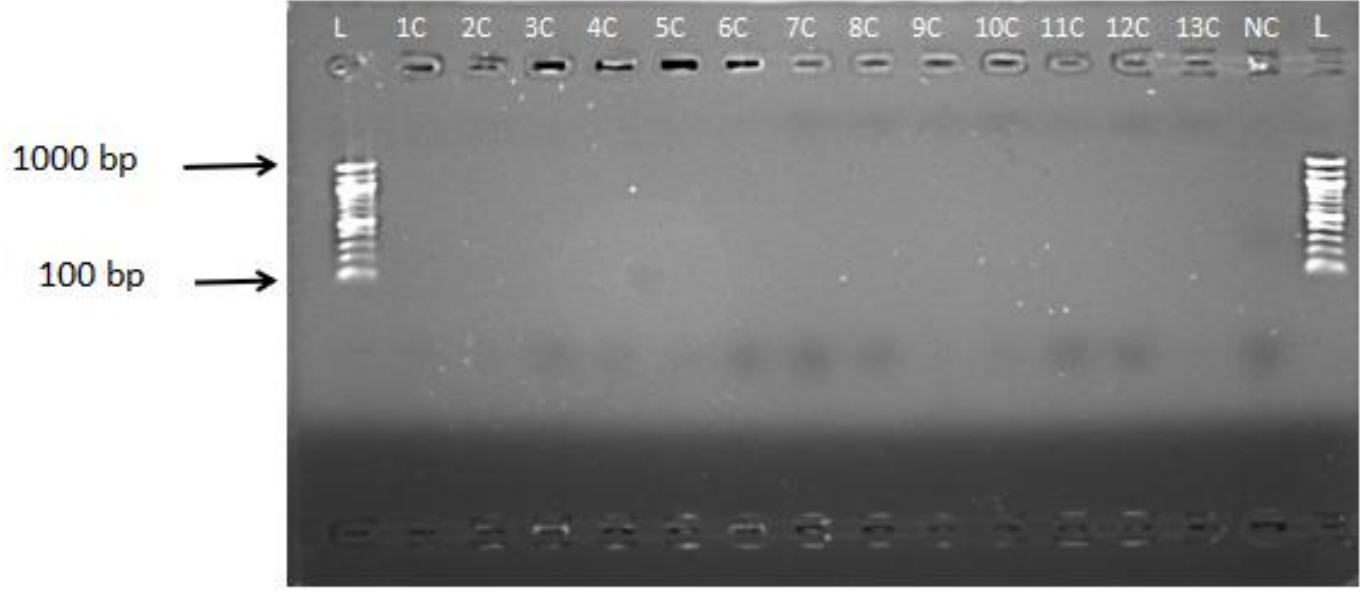


Figure 4: Reverse Transcriptase Polymerase Chain Reaction (RT-PCR) results for the apparently healthy participants (control participants). Metastatic Associated Long Adenocarcinoma Transcript 1 (MALAT 1) gene was analysed on a $1.0 \%$ agarose gel electrophoresis stained with ethidium bromide. $\mathrm{L}$ is $100-1000$ bp DNA ladder. $\mathrm{C}$ represents the control participants. All samples are negative for the MALAT-1 gene. Sample NC is a no template control.

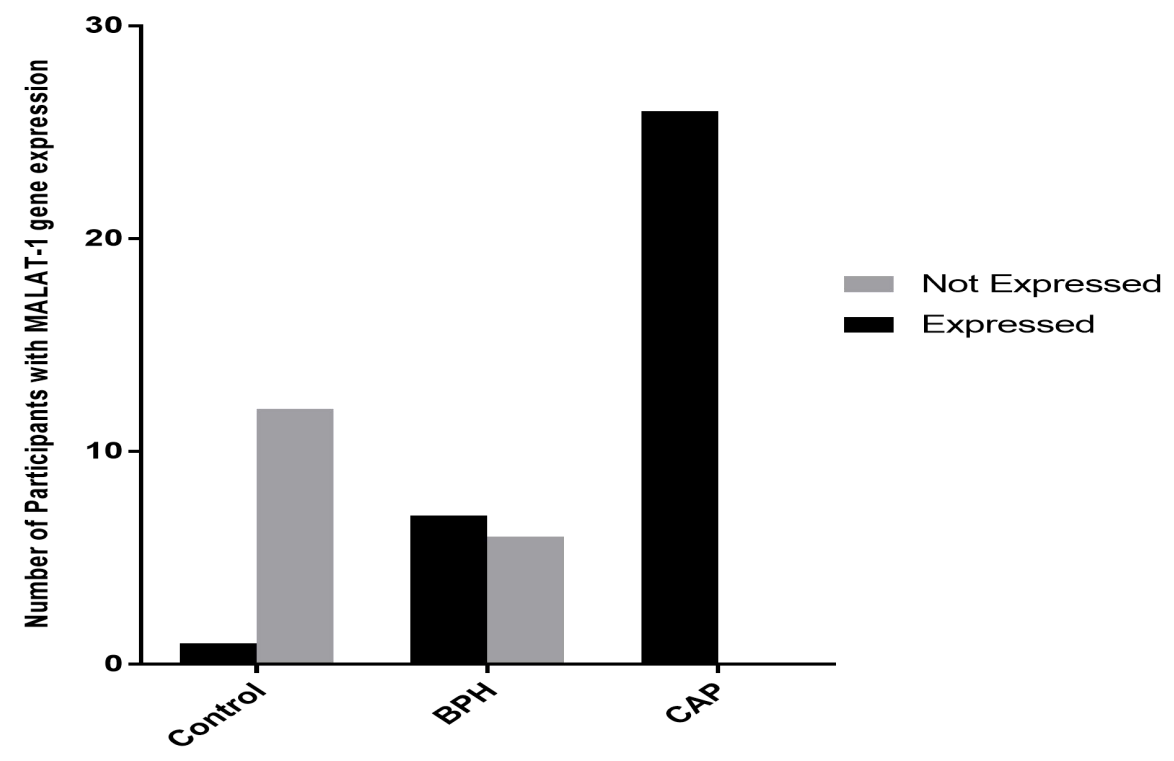

Figure 5: An overall multiple bar chart representation of the expression pattern of MALAT-1gene in all participants $\left(\chi^{2}=33.6, P=0.000\right) P$ is significant at $<0.001$

Table 3: Levels $(\mathrm{X} \pm$ SEM) of Genotoxicity biomarkers (8-OHdG and OGG1) and toxic metals (Cd and Pb) in Prostate Cancer Patients (Group A), Benign Prostatic Hyperplasia Patients (Group B) and the apparently healthy participants (Group C)

\begin{tabular}{ccccc}
\hline Participants & 8-OHdG & OGG1 & Cadmium & Lead \\
\hline GROUP A $(\mathrm{n}=26)$ & $97.24 \pm 3.53$ & $0.84 \pm 0.11$ & $0.68 \pm 0.02$ & $14.46 \pm 0.39$ \\
GROUP B (n=13) & $77.35 \pm 5.41$ & $1.82 \pm 0.28$ & $0.59 \pm 0.05$ & $13.08 \pm 0.40$ \\
GROUP C (n=13) & $54.4 \pm 4.29$ & $2.81 \pm 0.38$ & $0.51 \pm 0.04$ & $11.62 \pm 0.89$ \\
F-value & 25.51 & 19.89 & 6.46 & 6.99 \\
P-value & $<0.000$ & $<0.000$ & 0.003 & 0.002 \\
Post Hoc Analysis & & & & \\
GROUP A VS B & 0.002 & 0.003 & 0.069 & 0.079 \\
GROUP A VS C & $<0.000$ & $<0.000$ & 0.001 & 0.001 \\
GROUP B VS C & 0.002 & 0.010 & 0.155 & 0.106 \\
\hline
\end{tabular}

\section{Discussion}

This study used a prostate specific gene (MALAT-1) to establish the presence prostate cancer in the participants. Metastasis-associated lung adenocarcinoma transcript 1 (MALAT-1) is a type of lncRNAs and recent clinical studies have highlighted it as a promising biomarker to aid in cancer diagnosis and prognosis. ${ }^{[17]}$
The result from this study showed up regulation of MALAT-1 gene in prostate cancer patients and some benign prostatic hyperplasia patients, meaning there is a possibility of mutation in the DNA of the prostate cancer and benign prostatic hyperplasia patients as revealed by oxidation stress and the high level of the heavy metals. This gene was however down regulated in the control participants used. This is supported by 
the study of ${ }^{[20]}$ who observed that up regulation of MALAT-1 gene was involved in the progression of castration resistant prostate cancer and was associated with the maintenance of tumorigenicity. The expression of MALAT-1 has been shown to be regulated by numerous genes and proteins during its transcriptional and post-transcriptional processing. It has been reported that $\mathrm{Sp} 1$ transcription factor and the histone demethylase JMJD1A regulates the expression of MALAT-1 by binding to the gene promoter and thereby affecting the transcription processing. The histone de-methylase JMJD1A induces cell migration and invasion of prostate cancer cells by up- regulating the expression of the long noncoding RNA MALAT-1. 24

Reactive Oxygen Species (ROS) play essential roles in humans and is needed at low concentrations for a number of physiological activities such as cell death, immune defence against pathogens, induction of mitogenic response, intracellular cell signalling and homeostasis ${ }^{[6]}$. Imbalance between the production of free radicals (ROS) and the body's ability to readily detoxify these reactive intermediates results in oxidative stress. Under oxidative stress conditions, free radicals generated in excessive amounts can result in severe damage to the DNA, proteins and lipids which a resultant compromise in cell health and development of diseases ${ }^{[7]}$. The mutagenic effect of ROS is not restricted to DNA damage but can also result in attack on protein and lipid molecules. The lower concentration of the DNA guardian (OGG1) in prostate cancer patients than in the other subjects could have been as a result of oxidative stress, as the exposure to free radicals causes an imbalance in the antioxidant defence system. This oxidative stress may also have resulted in the higher concentration of $8-\mathrm{OHdG}$ in the cancer patients hence over expression of the gene; Oxidative damage to cellular lipids initiates' lipid peroxidation which results in the production of a range of mutagenic products that can alter cellular functions and increase cancer initiation and progression ${ }^{[8]}$. In addition, ROS-induced protein damage to DNA repair enzymes have been suggested as a possible reason for increased susceptibility of mutations which results in carcinogenesis. Hence, cancer can results from an imbalance between DNA damage and repair ${ }^{[9]}$.
8 -Hydroxy-2 $2^{1}$-deoxyguanosine $(8-\mathrm{OHdG})$ is one of the major oxidative modifications in the DNA generated by the hydroxylation of the deoxyguanosine residues. In an effective antioxidant defense system, it is usually excised from the DNA by enzymatic repair system resulting in its free circulation in the blood $[10,11]$. 8Oxoguanine DNA Glycosylase $\left(\mathrm{OGG}_{1}\right)$ being a major mutagenic lesion ${ }^{[12]}$ repairs oxidative DNA damage, through processes involving lesion recognition, changes in DNA structure, insertion of the 8-oxoguanine containing DNA double helix into the active site, base excision and strand cleavage [11, $13,14]$.

Based on epidemiological data, cadmium which represents a potential human and environmental hazard has been shown to be strongly associated with cancer mortality and morbidity in humans including pancreatic cancer, lung, non-Hodgkin lymphoma, leukaemia, ovarian and uterine cancers ${ }^{[28]}$. Cadmium as a nonessential heavy metal has been established as a toxic and carcinogenic because of its ability to induce DNA damage and interfere with cell signalling. The higher $(\mathrm{P}<0.05)$ cadmium level observed in CAP patients during this study has been reported by other researchers. In Wielkopolska region of Poland for instance high levels of cadmium observed in the hair of female population with different types of cancers when screening for trace elements. These high levels of cd could have been as a result of expose of the prostate cancer patients to free radicals in the environment resulting to oxidative stress. Marouf [27] reported differently when he considered the association between serum heavy metals level and cancer incidence in darbandikhan and kalar Area Kurdistan Region, he observed a higher level of cadmium in the control participants than in the CAP patients. These higher significant values obtained in our study may have been as result of environmental exposure of the CAP patients to the various sources cadmium (car batteries, phosphate fertilizers, environmental wastes) in Benin-City.

Excessive exposure to lead has been shown to have negative impact human health. The high levels of lead reflect toxicity in the studied group of patient. A number of researches suggest that exposure to lead increases greatly the susceptibility 
to cancer. The proposed mechanism of action is by exertion of different toxic effects by interfering with the repair mechanism of DNA following genotoxicity, this consequently impede the cells ability to elicit appropriate response to genotoxic insults. ${ }^{[25,26]}$ This is supported by the findings of Marouf ${ }^{[27]}$ who observed high levels of lead in CAP patients compared to control participants.

\section{Conclusion}

DNA damage as reflected in lower levels of plasma 8-Oxoguanine DNA Glycosylase and high levels of 8 -Hydroxy- $2^{1}$-deoxyguanosine is an evidence of genotoxic insult causing mutation in MALAT-1 gene. As a consequence, MALAT-1 gene is up regulated in CAP patients indicating its clinical usefulness as a predictive, diagnosis and prognostic biomarker.

\section{References}

1 Torre LA, Bray F, Siegel RL, Ferlay J, LortetTieulent J, Jemal A. Global cancer statistics, 2012. CA Cancer J Clin 2015; 65(2): 87-108 [PMID: 25651787 DOI: 10.3322/caac.21262]

2 Ferlay J, Soerjomataram I, Dikshit R, Eser S, Mathers C, Rebelo M, Parkin DM, Forman D, Bray F. Cancer incidence and mortality worldwide: sources, methods and major patterns in GLOBOCAN 2012. Int J Cancer 2015; 136(5): E359-386 DOI: $10.1002 / \mathrm{ijc} .29210$

3 Agalliu I, Adebiyi AO, Lounsbury DW, Popoola O, Jinadu K, Amodu O, Paul S, Adedimeji A, Asuzu C, Asuzu M, Ogunbiyi OJ, Rohan T, Shittu OB. The feasibility of epidemiological research on prostate cancer in African men in Ibadan, Nigeria. BMC Public Health 2015; 15: 425 DOI: 10.1186/s12889015-1754-X

4 Gutschner T, Diederichs S. The hallmarks of cancer: a long non-coding RNA point of view. $\boldsymbol{R N A}$ Biol 2012; 9(6): 703-719 DOI: 10.4161/rna.20481

5 Pizzino G, Irrera $\mathrm{N}$, Bitto $\mathrm{A}$, Pallio $\mathrm{G}$, Mannino F, Arcoraci V, Aliquo F, Minutoli L, De Ponte C, D'Andrea P, Squadrito F, Altavilla D. Cadmium-Induced Oxidative Stress Impairs
Glycemic Control in Adolescents. Oxid Med Cell Longev 2017; 2017: 6341671 DOI: $\underline{10.1155 / 2017 / 6341671}$

6 Birben E, Sahiner UM, Sackesen C, Erzurum S, Kalayci O. Oxidative stress and antioxidant defense. World Allergy Organ J 2012; 5(1): 919 DOI: 10.1097/WOX.0b013e3182439613

7 Barrera G. Oxidative stress and lipid peroxidation products in cancer progression and therapy. ISRN Oncol 2012; 2012: 137289 DOI: $10.5402 / 2012 / 137289$

8 McAdam E, Brem R, Karran P. Oxidative Stress-Induced Protein Damage Inhibits DNA Repair and Determines Mutation Risk and Therapeutic Efficacy. Mol Cancer Res 2016; 14(7): 612-622 DOI: $10.1158 / 1541-$ 7786.MCR-16-0053

9 Plachetka A, Adamek B, Strzelczyk JK, Krakowczyk L, Migula P, Nowak P, Wiczkowski A. 8-hydroxy-2'-deoxyguanosine in colorectal adenocarcinoma--is it a result of oxidative stress? Med Sci Monit 2013; 19: 690-695 DOI: 10.12659/MSM.883999

10 Izumi T, Wiederhold LR, Roy G, Roy R, Jaiswal A, Bhakat KK, Mitra S, Hazra TK. Mammalian DNA base excision repair proteins: their interactions and role in repair of oxidative DNA damage. Toxicology 2003; 193(1-2): 4365 DOI: $\underline{10.1016 / \mathrm{s} 0300-483 \times(03) 00289-0}$

11 Kasprzak KS. Oxidative DNA and protein damage in metal-induced toxicity and carcinogenesis. Free Radic Biol Med 2002; 32(10): 958-967 DOI: $10.1016 / \mathrm{s} 0891-$ 5849(02)00809-2

12 Youn CK, Kim SH, Lee DY, Song SH, Chang IY, Hyun JW, Chung MH, You HJ. Cadmium down-regulates human OGG1 through suppression of Sp1 activity. J Biol Chem 2005; 280(26): 25185-25195 [PMID: 15760895 DOI: 10.1074/jbc.M412793200]

13 Zharkov DO, Rosenquist TA. Inactivation of mammalian 8-oxoguanine-DNA glycosylase by cadmium(II): implications for cadmium genotoxicity. DNA Repair (Amst) 2002; 1(8): 661-670 [PMID: 12509288]

14 Brosnan CA, Voinnet O. The long and the short of noncoding RNAs. Curr Opin Cell Biol 2009; 21(3): 416-425 [PMID: 19447594 DOI: 10.1016/j.ceb.2009.04.001] 
15 Inamura K. Major Tumor Suppressor and Oncogenic Non-Coding RNAs: Clinical Relevance in Lung Cancer. Cells 2017; 6(2) DOI: $10.3390 /$ cells6020012

16 Deng H, Wang JM, Li M, Tang R, Tang K, Su Y, Hou Y, Zhang J. Long non-coding RNAs: New biomarkers for prognosis and diagnosis of colon cancer. Tumour Biol 2017; 39(6): 1010428317706332 [PMID: 28643604 DOI: 10.1177/1010428317706332]

17 Gutschner T, Hammerle M, Diederichs S. MALAT1 -- a paradigm for long noncoding RNA function in cancer. $\boldsymbol{J}$ Mol Med (Berl) 2013; 91(7): 791-801 [PMID: 23529762 DOI: 10.1007/s00109-013-1028-y]

18 Pang EJ, Yang R, Fu XB, Liu YF. Overexpression of long non-coding RNA MALAT1 is correlated with clinical progression and unfavorable prognosis in pancreatic cancer. Tumour Biol 2015; 36(4): 2403-2407 DOI: $10.1007 / \mathrm{s} 13277-014-2850-8$

19 Ren S, Liu Y, Xu W, Sun Y, Lu J, Wang F, Wei M, Shen J, Hou J, Gao X, Xu C, Huang J, Zhao Y, Sun Y. Long noncoding RNA MALAT-1 is a new potential therapeutic target for castration resistant prostate cancer. $\boldsymbol{J}$ Urol 2013; 190(6): 2278-2287 [PMID: 23845456 DOI: 10.1016/j.juro.2013.07.001]

20 Fong BM, Siu TS, Lee JS, Tam S. Determination of mercury in whole blood and urine by inductively coupled plasma mass spectrometry. J Anal Toxicol 2007; 31(5): 281-287 DOI: $10.1093 /$ jat/31.5.281

21 Yin B, Whyatt RM, Perera FP, Randall MC, Cooper TB, Santella RM. Determination of 8hydroxydeoxyguanosine by an immunoaffinity chromatography-monoclonal antibody-based ELISA. Free Radic Biol Med 1995; 18(6): 1023-1032 DOI: $\quad \underline{10.1016 / 0891-}$ 5849(95)00003-g
22 Tee AE, Ling D, Nelson C, Atmadibrata B, Dinger ME, Xu N, Mizukami T, Liu PY, Liu B, Cheung B, Pasquier E, Haber M, Norris MD, Suzuki T, Marshall GM, Liu T. The histone demethylase JMJD1A induces cell migration and invasion by up-regulating the expression of the long noncoding RNA MALAT1. Oncotarget 2014; 5(7): 1793-1804 DOI: 10.18632/oncotarget.1785

23 Garcia-Leston J, Mendez J, Pasaro E, Laffon B. Genotoxic effects of lead: an updated review. Environ Int 2010; 36(6): 623-636 [PMID: 20466424 DOI: $10.1016 /$ j.envint.2010.04.011]

24 Chinde S, Kumari M, Devi KR, Murty US, Rahman MF, Kumari SI, Mahboob M, Grover P. Assessment of genotoxic effects of lead in occupationally exposed workers. Environ Sci Pollut Res Int 2014; 21(19): 11469-11480 [PMID: 24906834 DOI: $\underline{10.1007 / \mathrm{s} 11356-014-}$ 3128-9]

25 Marouf BH. Association between serum heavy metals level and cancer incidence in darbandikhan and Kalar Area, Kurdistan Region, Iraq. Niger J Clin Pract 2018; 21(6): 766-771 DOI: $10.4103 /$ njcp.njcp $384 \_16$

26 Adams SV, Quraishi SM, Shafer MM, Passarelli MN, Freney EP, Chlebowski RT, Luo J, Meliker JR, Mu L, Neuhouser ML, Newcomb PA. Dietary cadmium exposure and risk of breast, endometrial, and ovarian cancer in the Women's Health Initiative. Environ Health Perspect 2014; 122(6): 594-600 DOI: 10.1289/ehp.1307054

27 Urani C, Melchioretto P, Fabbri M, Bowe G, Maserati E, Gribaldo L. Cadmium Impairs p53 Activity in HepG2 Cells. ISRN Toxicol 2014; 2014: 976428 DOI: 10.1155/2014/976428

28 Czerny B, Krupka K, Ozarowski M, SeremakMrozikiewicz A. Screening of trace elements in hair of the female population with different types of cancers in Wielkopolska region of Poland. Scientific World Journal 2014; 2014: 953181 DOI: $\underline{10.1155 / 2014 / 953181}$ 